\title{
38. SEDIMENTOLOGIC STUDY OF MID-CRETACEOUS CARBONACEOUS LIMESTONES AT SITES 549 AND 550, NORTHEAST ATLANTIC ${ }^{1}$
}

\author{
P. C. de Graciansky, École Nationale Supérieure des Mines de Paris \\ and \\ E. Gillot, Institut des Sciences de la Terre, Université de Dijon²
}

\begin{abstract}
Four holes at Sites 549 and 550 located along a transect across the northwestern European continental margin recovered calcareous carbonaceous sediments of mid-Cretaceous age. They are part of the more widespread occurrence of North Atlantic black shales. At both sites, alternating dark laminated calcareous siltstone and burrowed light-colored calcareous siltstone were recovered. At Site 549 the sequence is lower Albian to lower middle Albian and is $181 \mathrm{~m}$ thick. Terrigenous influx to the site was apparently relatively important because of its shallow paleodepth (500 m) and the proximity of an emerged land mass. At Site 550 , which was the deepest site ( $2000 \mathrm{~m}$ paleodepth), biogenic calcareous sediments dominate the $91-\mathrm{m}$ thick sequence of upper Albian to middle Cenomanian strata directly overlying oceanic basalt. A problem is raised by the cyclic character of the deposits. The cycles may have been climatically induced by consequent variations in turnover of bottom waters. Bottom currents seem also to have played a role in their formation. In spite of the similar aspect of the sediments at both sites, the organic geochemistry data document differences between their environments of deposition. At Site 549 the low organic carbon content $(<1 \%)$ and the absence of marine organic matter in the dark facies both suggest that the bottom waters were moderately to well oxygenated. In contrast, at Site 550 the preservation of marine organic matter within the dark lithology implies a temporary restriction and oxygen depletion in the bottom waters during Cenomanian time. The coeval Cenomanian chalks deposited at the shallower Site 549 were well-oxygenated, pure white sediments. The narrow and complex geometry of the depression located in the oceanic trough, which opened during the Cenomanian, was probably favorable to restricting circulation of deep waters and also to the preservation of middle Cenomanian sediments, which have not been found very frequently in the deep North Atlantic.
\end{abstract}

\section{INTRODUCTION}

During Leg 80 of the International Phase of Ocean Drilling, holes were drilled at four sites located along a transect across the European continental margin in the North Atlantic at Goban Spur (Fig. 1). Holes at two of these sites (Holes 549 and 550B), which were spudded at 2533 and $4432 \mathrm{~m}$ below sea level, respectively, sampled alternating dark and light-colored calcareous siltstones and mudstones of mid-Cretaceous age. The significant total organic carbon (TOC) content of the dark sediment suggests that it is related to the widespread North Atlantic mid-Cretaceous black shales.

The organic geochemistry determinations given elsewhere in this volume (Waples and Cunningham, this volume) are here complemented by sedimentologic observations. The purpose of our study is to determine the nature and origin of the sedimentary components and the mechanisms of their deposition. Thin-section examination and X-ray mineralogic determinations (see Appendix II, this volume) have been used throughout this study, and special consideration has been given to the cyclic character of the deposits.

\footnotetext{
${ }^{1}$ Graciansky, P. C. de, Poag, C. W., et al., Init. Repts. DSDP, 80: Washington (U.S. Govt, Printing Office).

2 Addresses: (Graciansky) École Nationale Supérieure des Mines de Paris, 60 Bd. Saint Michel, 75272 Paris Cedex 06, France; (Gillot) Institut des Sciences de la Terre, Université de Dijon, 6 Bd. Gabriel, 21100, Dijon, France.
}

\section{SITE 549: THE ALBIAN SEDIMENTARY SEQUENCE}

At Site 549 the sediments at depths from 660 to 479 $\mathrm{m}$ BSF are lower Albian to lower middle Albian (Cores 52 to 32 ; Unit 6 of the site chapter).

The lower and upper limits of this interval (total thickness: $181 \mathrm{~m}$ ) are defined mainly by sharp deflections on the logging curves. The underlying lithology is a dolomitic sandstone of unknown age; the overlying one is white chalk of Cenomanian age.

\section{The Main Lithologic Types}

This relatively homogeneous unit is composed mainly of silty limestone of grayish to dark gray color with two lithologic end members.

\section{Dark Calcareous Siltstone}

The dark sediments are deposited in beds up to a maximum of $20 \mathrm{~cm}$ in thickness having well preserved internal millimetric laminations and rare bioturbation. The color ranges from N4 to N6 of the conventional Munsell chart. According to thin-section examination, fossil remains are mostly foraminifers. Among these, hedbergellids are more abundant than benthic forms, which are represented by a few quartzose agglutinating specimens at the base of the unit. The foraminifers are associated with subordinate siliceous radiolarians (a few with calcite-filled molds), sponge spicules (more frequently dis- 


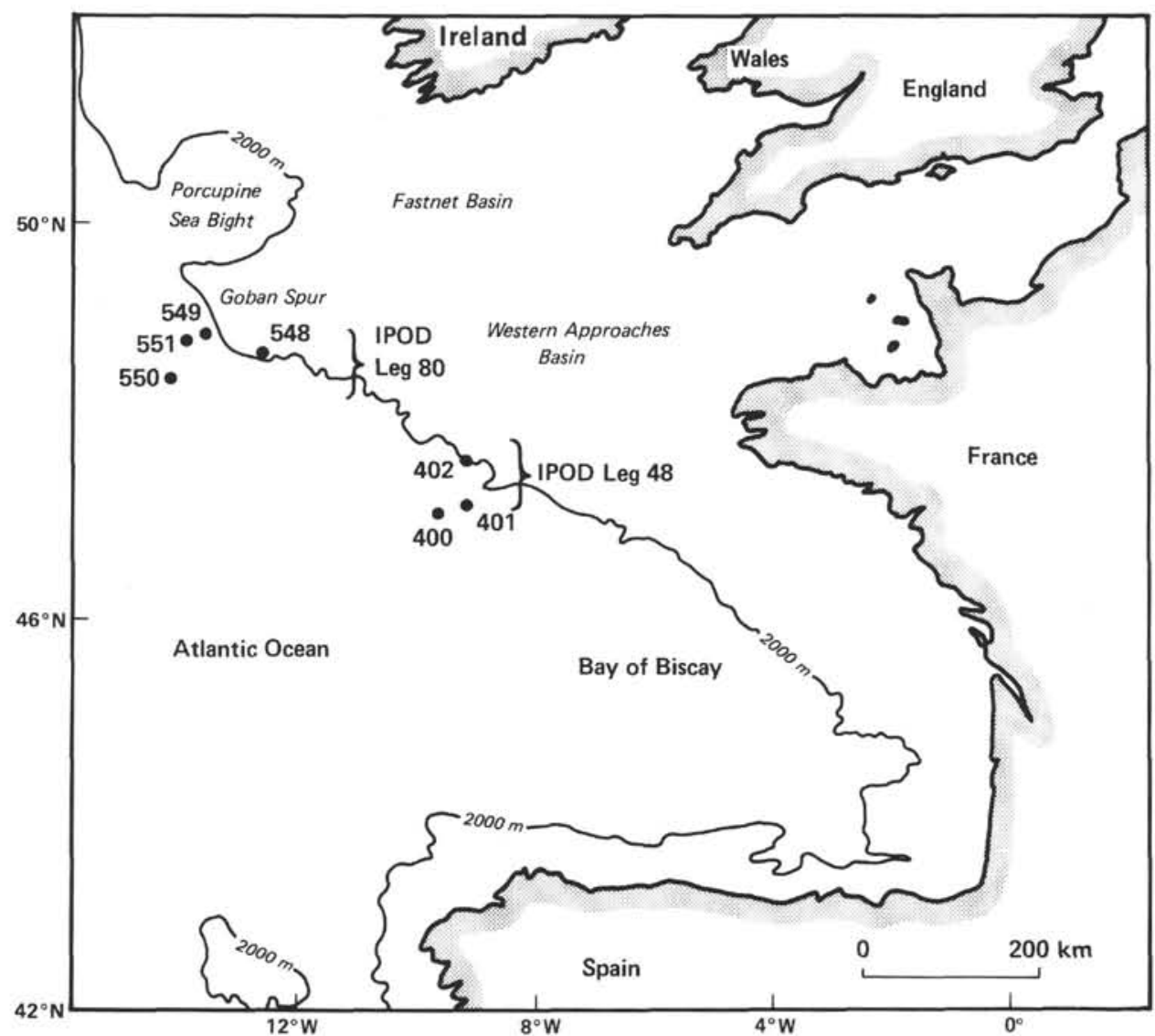

Figure 1. Location map.

solved and with sparite-cemented molds than the radiolarians), and small, sparse shell debris.

Fossil remains and silt-sized quartz grains are supported by a micritic calcareous matrix which also contains disseminated pyrite and plant fragments. The matrix is generally microsparite; sparite is limited to the bioclastic components.

\section{Light-Colored Calcareous Siltstone}

Light gray to white bands are 10 to $20 \mathrm{~cm}$ thick and occur at 2- to 3-m intervals between sediments of intermediate character. Upper and lower contacts are gradational within 2 to $3 \mathrm{~cm}$. The light color is related to the relative abundance of molluscan shell fragments and hedbergellids; both bioclasts and calcareous matrix are severely recrystallized. Radiolarians, sponge spicules, pyrite, and organic matter are much rarer than in the dark calcareous siltstone. Therefore it seems that the light color is due both to (1) the dominance of the calcareous components over pyrite and organic debris and (2) the abundance of diagenetic sparite, the formation of which was very likely related to the coarser grain of the sediment. In fact, primary stratification and bioturbation are widely obliterated by recrystallization.

\section{Calcareous Siltstone of Intermediate Character}

Calcareous siltstone layers 1 to $2 \mathrm{~m}$ in thickness constitute the main part of the interval. They grade into the end members just discussed, with variable amounts of hedbergellids, radiolarians, molluscan fragments, sponge spicules, and pyrite, along with organic matter in the matrix. Quartz is sparse and the grains are corroded. The development of diagenetic sparite is variable and more often affects the bioclasts than the matrix. Color banding varies between light gray (N3) and dark gray (N4).

\section{Mineralogic Components and Their Vertical Distribution}

\section{Calcite}

The calcite content varies between 30 and $85 \%$ (Fig. $2)$. The higher calcite contents generally occur in the light-colored facies, which are richer in shell debris and more recrystallized. There is, however, no absolute correlation between color and calcite content because some of the darker sediments are also carbonate rich (e.g., $549-43-2,68-69 \mathrm{~cm}$ has $\left.85 \% \mathrm{CaCO}_{3}\right)$.

\section{Quartz}

According to X-ray diffraction data, the average quartz content is between 10 and $20 \%$, and the lower part of the interval (Cores 49 through 45 ) is somewhat richer in quartz. Quartz grains are generally small $(<200 \mu \mathrm{m})$ and commonly show traces of diagenetic corrosion. Some light-colored siltstone beds show a relative enrichment in quartz which illustrates the more detrital character of this lithology. 


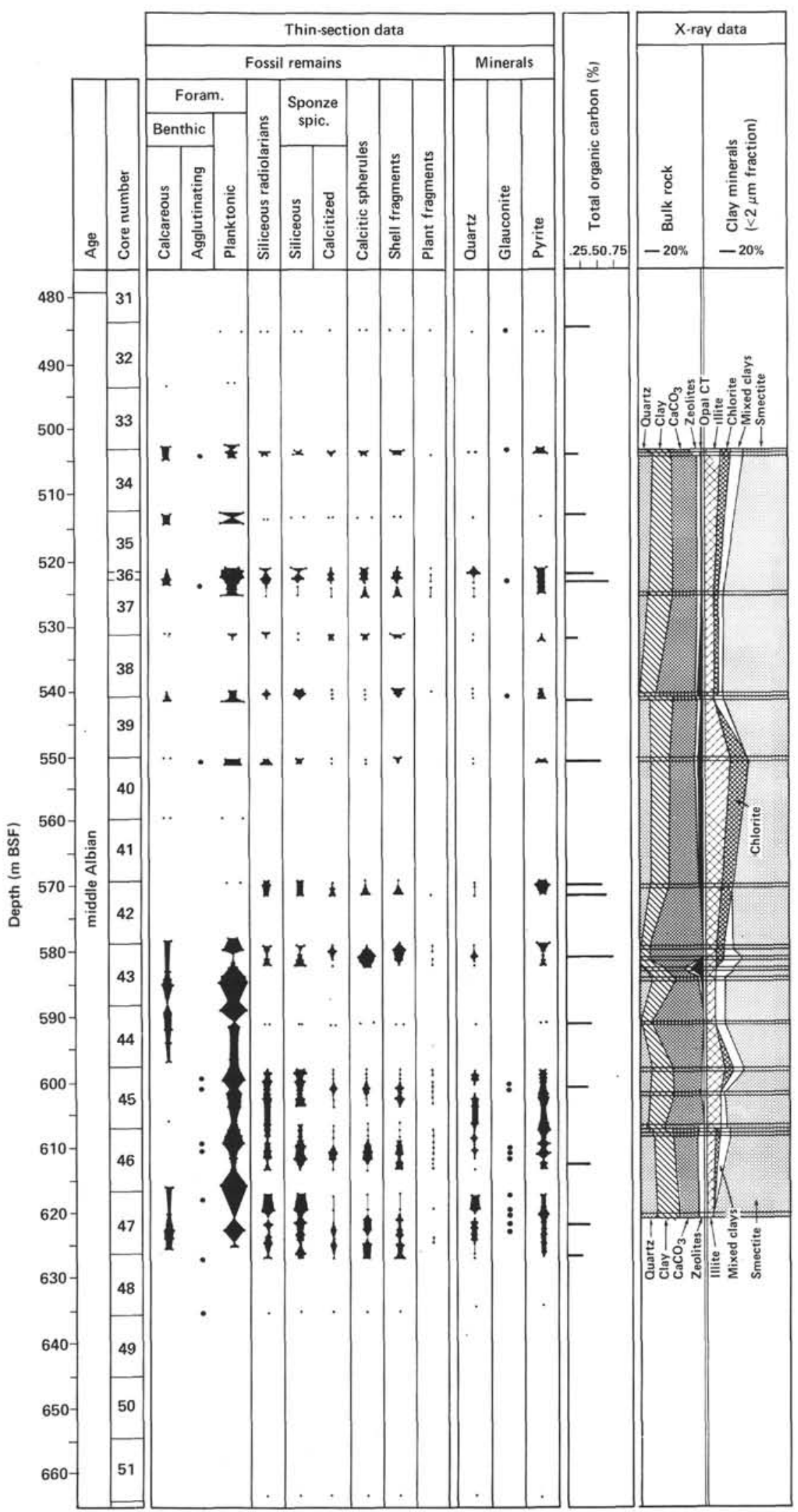

Figure 2. Vertical distribution of Albian biogenic and mineralogic components, Site 549. Estimation of foraminiferal abundance includes J. Sigal's observations of sieve residues (pers. comm., 1981) and our observation of thin sections. Calcitic spherules are sparite infillings of isolated foraminiferal chambers or calcite filled radiolarian molds. Glauconite from X-ray diffraction (G. S. Odin, pers. comm., 1982). Other mineralogical determinations are from M. Thiry (pers. comm., 1982). TOC contents are from shipboard analysis (Waples and Cunningham, this volume). 


\section{Mica and Feldspar}

In addition to quartz, muscovite and chlorite flakes are the most abundant detrital minerals. They are generally oriented parallel to the bedding. Plagioclase is rarer and is deeply etched by diagenetic dissolution. Mica and feldspar mineralogies were determined from thin sections.

\section{Pyrite}

Pyrite is ubiquitous as tiny crystals or framboids, either isolated or in small clusters. It frequently fills foraminifer chambers and replaces radiolarian tests. It is visible only in thin section and was not detected by X-ray investigations.

\section{Opal-CT and Clinoptilolite}

Opal-CT makes up about 5 to $25 \%$ of the sediment and zeolites up to $5 \%$. Both are detectable by X-ray methods in nearly all the samples. Their occurrence is clearly related to radiolarians, except where radiolarians have been dissolved and the molds cemented by calcite, which is often the case in the light-colored siltstone. This suggests that dissolution and removal of biogenic silica was not accompanied by the growth of opal-CT and clinoptilolite. Indeed, high $\mathrm{CaCO}_{3}$ contents are not favorable to the growth of opal-CT or zeolite (Karpoff et al., 1981; Kastner et al., 1977).

\section{Glauconite}

A greenish stain indicative of glauconite is present throughout the interval, but it is only detectable by $\mathrm{X}$ ray diffraction after manual separation of grains. Two main occurrences of glauconite can be defined from thinsection examination. The first occurrence is glauconitic grains apparently reworked from shallower depths, probably from the shelf. These are isolated grains, light to dark green in color with sharp or diffuse edges. Some replace planktonic foraminifer tests and sponge spicules.

The other type probably reflects deeper environmental conditions of formation (G. S. Odin, personal communication, 1982). This glauconite has most likely formed in situ; it is common in burrows and along small-scale laminations as tiny or diffuse grains. In some cases glauconite-stained laminations were observed between lightcolored beds below and darker ones above. This may indicate a temporary reduction of the sedimentation rate. The location of Site 549 on the top of an escarpment would probably have been favorable to the formation of glauconite (Odin and Stephan, 1981).

\section{Characteristics of the Organic Matter}

The TOC contents are generally low, between 0.17 and $0.72 \%$. The higher TOC contents occur in samples that contain numerous, large wood fragments (Waples and Cunningham, this volume). In the light-colored (N6 and N7) lithology the TOC is lower than average, whereas the $\mathrm{CaCO}_{3}$ content is higher than average (Fig. 3).

The darkness of the sediment does not correlate directly with the TOC content (Fig. 4), because the color may also depend on the pyrite content, the type and orientation of clay minerals, and the abundance of bioturbation.
Geochemical analysis suggests that most of the organic carbon is of terrestrial rather than marine origin (Waples and Cunningham, this volume). This is compatible with significant oxygenation of the bottom waters, as shown by the bioturbation observed throughout the interval, and does not necessarily imply a continuous reducing near-bottom environment.

\section{Cyclic Sedimentation and Paleoenvironmental Reconstruction}

The abundance of fine-grained sediment suggests that sedimentation took place in a very low energy environment. In spite of generally poor recovery in the interval, a typical cycle of deposition (Fig. 3) can be defined in Cores 47 through 42 which illustrates the varying conditions of deposition. Darker lithologies typically grade upward progressively into lighter ones. In contrast, the tops of the light-colored sediment beds are marked by sharp contacts which in many places are underlined by glauconite-rich bands.

Such cycles could have resulted from climatically induced variations in oceanic turnover and oxygenation of bottom waters. This explanation fits well with modern data on cyclic stratification. Indeed, the average duration of deposition of one couplet of dark/light layers is estimated for this study as 20,000 years $^{3}$; this correlates with the Earth's 19,000 to 23,000 year precession cycle (Schwarzacher and Fischer, 1982).

The asymmetry of most of the observed couplets might be the result of the episodic arrival of bottom currents which could have themselves resulted from the above-mentioned climatic cycles. In fact, the energy of deposition seems to have increased from the bottom to the top of each individual cycle. At the base of each cycle, only tiny organic fragments and some planktonic foraminifers were laid down in coccolith-rich mud (Fig. 3). Coarser grains, mainly shell fragments, accumulated higher in the section in the light-colored siltstones, finer particles probably having been swept away by bottom currents. At the top of each cycle currents probably prevented deposition of the relatively fine-grained sediment, causing a temporary interruption of deposition. At this moment conditions could have been favorable to in situ crystallization of glauconite (Odin and Stephan, 1981). Sedimentation could only resume when the current ceased or changed its course. Such pulsation might have favored the maintenance of a minimum oxygen content on the sea bottom in spite of the low energy environment. This tentatively explains the lack of marine organic matter within the dark lithology.

\section{SITE 550: THE SEDIMENTARY SEQUENCE OF VRACONIAN ${ }^{4}$ TO MIDDLE CENOMANIAN AGE}

The sediments at depths from 685.2 to $594.35 \mathrm{~m}$ below seafloor are of Vraconian to middle Cenomanian age. They are from 550B-25-4 through 550B-15-4, $87 \mathrm{~cm}$, and correspond to Unit 5 of the site chapter (this vol-

\footnotetext{
${ }^{3}$ This estimate is derived from (1) counting the number of cycles per core, (2) estimating the equivalent time interval, and (3) calculating the ratio of cycles per unit time.

4 Vraconian (locus typicus, La Vraconne, France) is equivalent to upper Albian in European stratigraphy.
} 

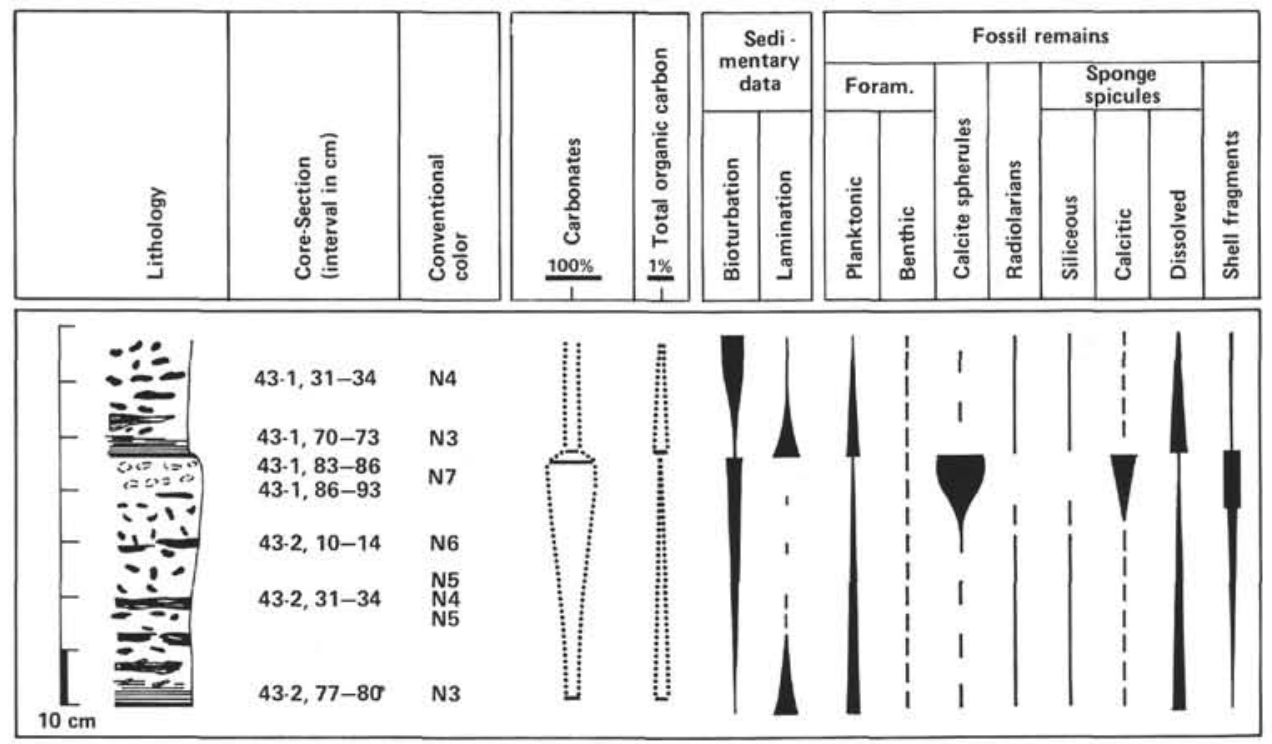

Figure 3. The basic depositional couplet of Albian age, Site 549. Calcitic spherules are sparite infillings of isolated foraminifer chambers or calcite-cemented radiolarian molds. $\mathrm{TOC}$ and $\mathrm{CaCO}_{3}$ determinations are from shipboard analysis (Waples and Cunningham, this volume).

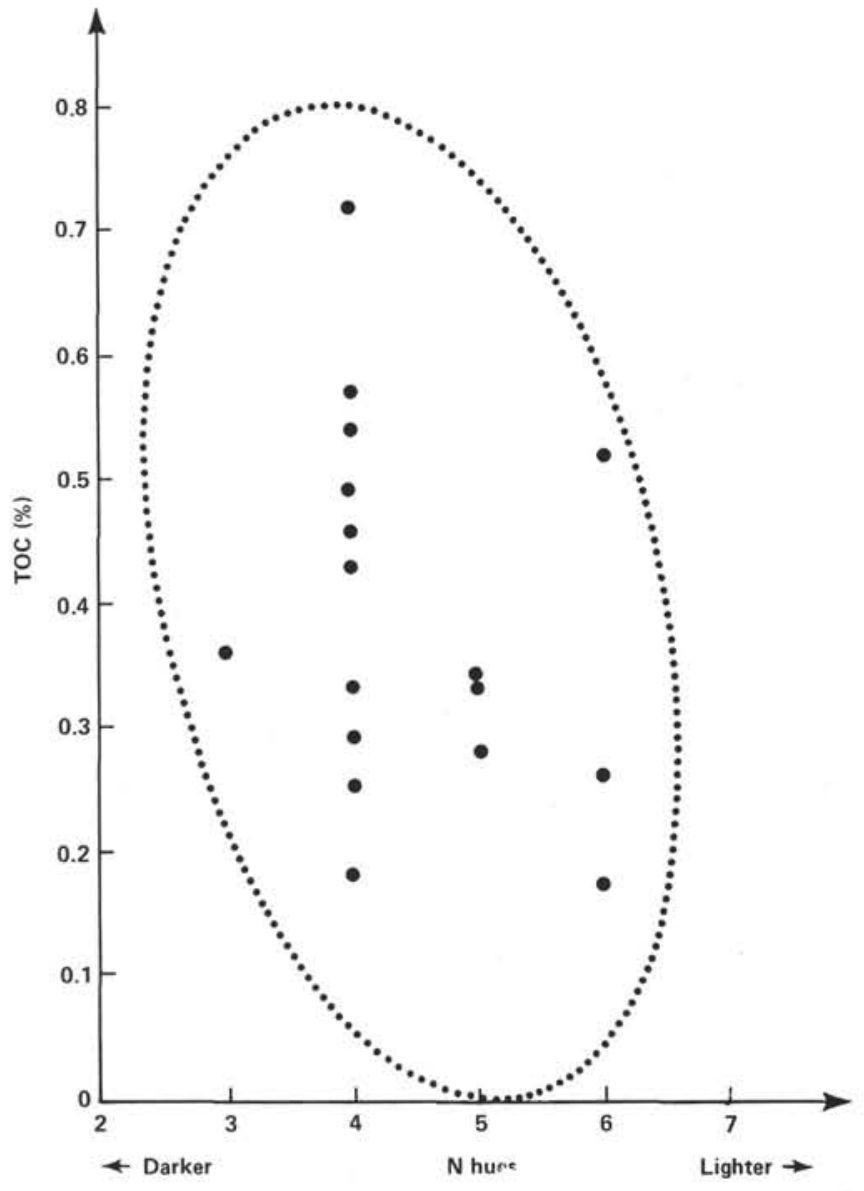

Figure 4. The relationship between TOC content and color of Albian sediments in calcareous siltstones at Site 549. The numbers on the $\mathrm{X}$-axis correspond to the $\mathrm{N}$-hues on the Munsell color chart. The correlation is only -0.3 . TOC contents are from shipboard analysis (Waples and Cunningham, this volume). ume). The Vraconian mudstone of Core 25 directly overlies basalt. The upper boundary is a deeply burrowed surface which underlies lower Senonian argillaceous mudstone.

The unit is composed mainly of alternating deposits of two kinds of calcareous mudstones: (1) a dark carbonaceous facies and (2) a silty light gray, pinkish or yellowish lithology with a low TOC content. On the basis of fluctuations in the sedimentologic and mineralogic characteristics, notably maximum TOC values, four subunits can be defined (Figs. 5 and 6). These are presented from the base to the top.

\section{Subunit 5d: Alternating Dark Gray Laminated and Light Gray Burrowed Mudstone}

Subunit $5 \mathrm{~d}$ is Vraconian in Core 25 and lower Cenomanian in Cores 24 through 21 . It is $33.7 \mathrm{~m}$ thick (685.2 $\mathrm{m}$ to $651.50 \mathrm{~m} \mathrm{BSF}$ ). The lower boundary is formed by the basalt on which the whole sedimentary pile of Site 550 is resting. The upper boundary is transitional with the overlying subunit and has been fixed arbitrarily at $0 \mathrm{~cm}$ of Core 21, Section 6, above which reddish to pinkish color appears.

\section{Lithologic Types}

\section{Light Gray Burrowed Calcareous Mudstone}

The light-colored lithology (N5, 5Y 5/1 to 7/1) is mottled by darker burrows (N3, N4). The $\mathrm{CaCO}_{3}$ content is between 45 and $55 \%$ and the TOC is low $(0.2-0.5 \%)$. Thin sections show planktonic foraminifers (hedbergellids, Rotalipora, and Heterohelix) set in a micritic matrix. Benthic foraminifers are rare and are mainly quartzose agglutinating forms (Ammodiscus and Haplophragmoides). Tiny shell debris is ubiquitous, and there are occasional Inoceramus prisms. Radiolarian tests are rare 


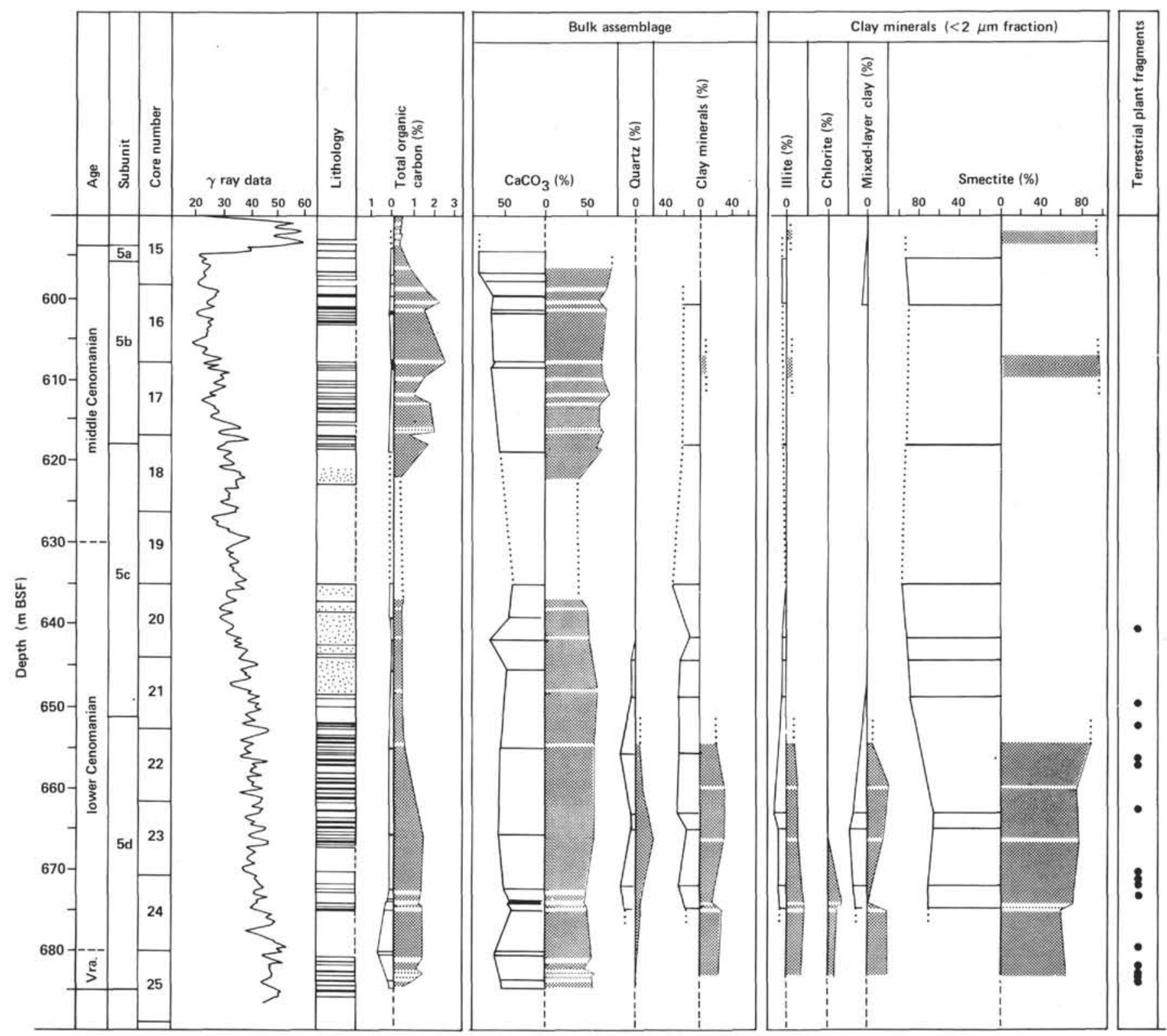

Figure 5. Vertical distribution of mineralogic components and TOC in the upper Albian (Vraconian) to Cenomanian of Site 550. Each column is divided into the two main end-member lithologies: dark carbonaceous mudstones are represented by the shaded areas on the right side of each column and lighter colored bioturbated mudstones by the single solid lines on the left side of each column. Note the correlation between plant debris occurrence (from thin sections) and quartz and varied clay assemblage content. Also note that the $\mathrm{CaCO}_{3}$ and quartz contents do not vary significantly between the light and dark lithologies. The mineralogic determinations are from M. Thiry (personal communication, 1982); TOC contents are from shipboard analysis (Waples and Cunningham, this volume). In the lithology column, solid symbol = dark calcareous mudstone; blank $=$ light colored calcareous mudstones; and dotted symbol = varicolored calcareous mudstone.

and molds are generally filled with calcite. Quartz grains are small and very rare and are generally dispersed in the matrix rather than arranged in laminae. Glauconite grains $50 \mu \mathrm{m}$ in diameter are scattered throughout.

\section{Dark Gray Laminated Calcareous Mudstone}

Variations in dark hues (N2, N3, 5Y 2/1 to 4/1) in these sediments mark the laminations; burrowing is uncommon. $\mathrm{CaCO}_{3}$ content varies from 55 to $65 \%$, which is higher than in the associated light-colored lithology. Also, the TOC content is higher: between 0.6 and $1.8 \%$.
Thin-section study shows that biogenic and detrital components are comparable to those of the alternating light-colored sediments, with the exception of lower quartz and glauconite contents. Dispersed kerogen and abundant pyrite are the characteristic components of this lithology. Also, diffused glauconite appears to occur in the laminations near the top.

\section{Clay Minerology}

The clay content averages $80 \%$ smectite, nearly $10 \%$ illite and mixed layer clays, and less than $5 \%$ chlorite (Fig. 5). This detrital clay association, which occurs in 


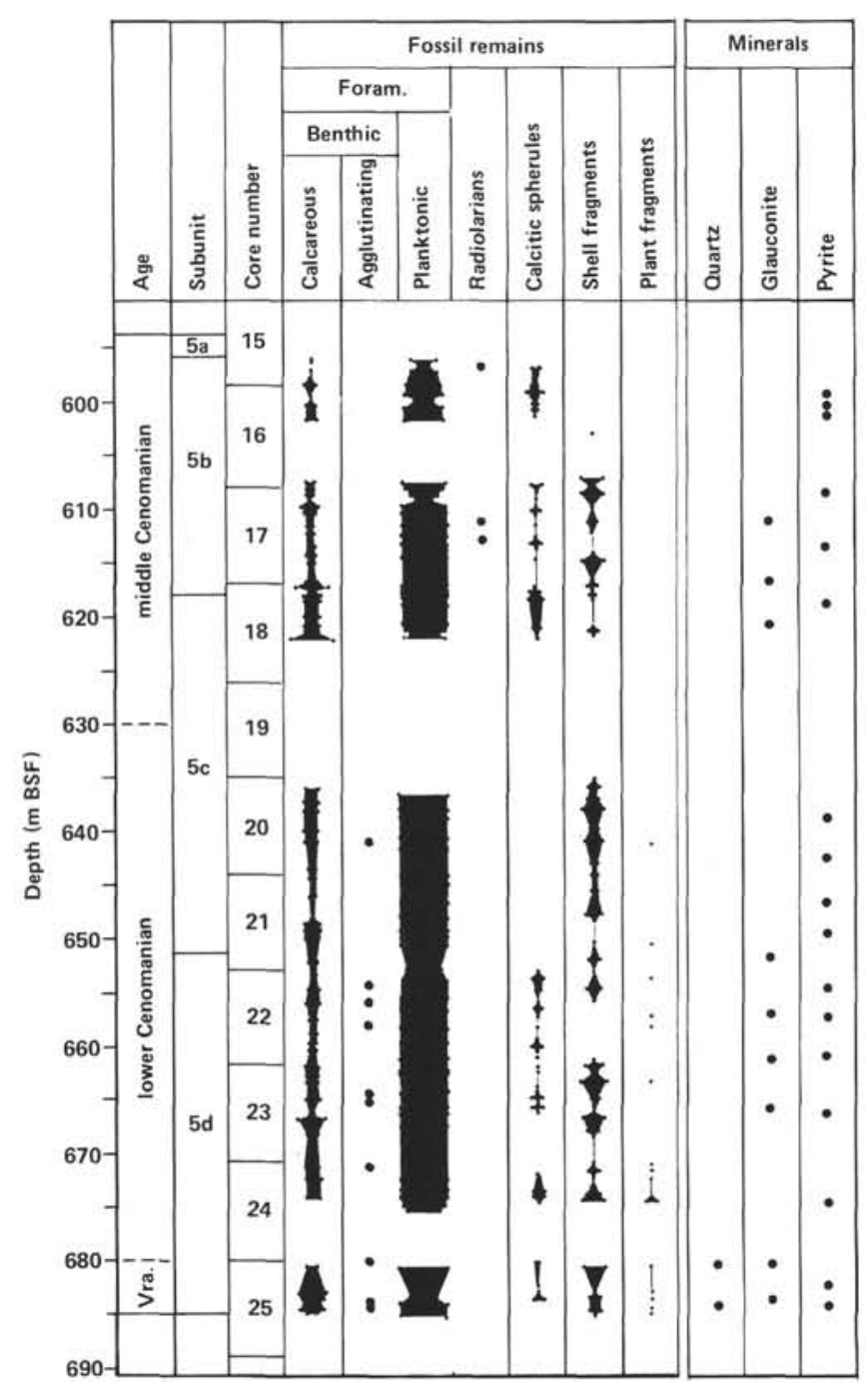

Figure 6. Vertical distribution of biogenic components in upper Albian (Vraconian) to Cenomanian sediments from thin-section inspection at Site 550. Estimation of foraminiferal abundance includes J. Sigal's observations on sieve residues (personal communication, 1981) and our observations from thin sections. Calcitic spherules are sparite infills of isolated foraminifer chambers or calcite-cemented radiolarian molds. Glauconite determined from X-ray diffraction by G. S. Odin (personal communication, 1982).

the lower part of the interval directly above the basalt, disappears upward as smectite becomes even more dominant over the other clay minerals. A significant difference between the two lithologic types is the presence of chlorite in the carbonaceous facies and its scarcity or absence in the light-colored facies. This difference is probably related to the presence of organic matter, which has apparently inhibited the diagenetic reaction of the chloritic, mixed-layer clay and the pure smectite. However, diagenetic alteration of chlorite seems to have taken place in the light-colored facies. In any case, this difference in clay mineralogy should not be interpreted as resulting from fluctuations in the detrital influx.

\section{Organic Geochemistry Data}

As previously stated, the TOC contents of the two lithologies are significantly different (Fig. 5). It can be shown that the thicker the carbonaceous beds, the higher the TOC content (Fig. 7).

Waples and Cunningham (this volume) have shown that carbonate content is slightly higher in organic-carbon-rich intervals (Figs. 8 and 9). These higher carbonate and carbon contents should be the result of a higher biogenic productivity. According to thin-section examination there is no evidence for enrichment in $\mathrm{CaCO}_{3}$ by diagenetic processes. A slightly different influx of terrigenous quartz and clay for the organic-rich versus organic-poor intervals could explain the difference.

Although fluctuations in $\mathrm{CaCO}_{3}$ and TOC contents can be correlated for individual complets, no clear relationship can be seen between these two parameters on the overall scale of the whole unit (Fig. 10).

Geochemical determinations (Waples and Cunningham, this volume) have established that the organic matter contained in the light-colored sediments is mainly residual. In the carbonaceous beds the organic matter is of composite origin, partly terrestrial and partly marine (Types II and III on the Van Krevelen diagram). The existence of Type II organic matter suggests the episodic presence of reducing conditions in the bottom waters.

\section{Cyclic Sedimentation and Paleoenvironmental Reconstruction}

The alternation of two sediment types, one containing preserved marine organic matter (Type II on the Van Krevelen diagram) and the other altered organic matter, implies alternating reducing and oxidizing conditions in the bottom waters. This suggests periods of relative restriction alternating with renewed bottom water circulation.

Two basic types of sedimentary cycles can be distinguished. First, laminated carbonaceous mudstones grade progressively through an intermediate facies into light gray burrowed mudstones, which in turn are gradational with the overlying carbonaceous mudstones. These cycles are thus symmetrical. Thicknesses of one complete cycle range from $0.50 \mathrm{~m}$ to $1 \mathrm{~m}$. A typical succession would include the following (Fig. 8B): (1) light gray, strongly burrowed calcareous mudstone; (2) light gray, burrowed calcareous mudstone; (3) medium gray, weakly burrowed calcareous mudstone; (4) dark gray, carbonaceous, laminated calcareous mudstone; (5) medium

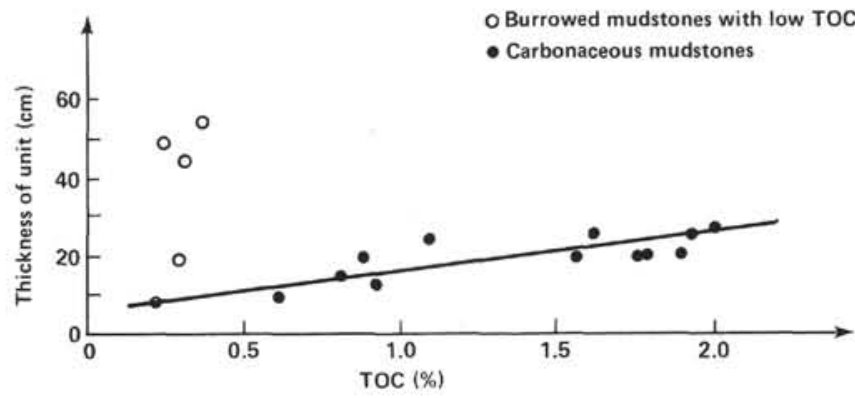

Figure 7. Correlation between TOC content and thickness of upper Albian (Vraconian) to Cenomanian carbonaceous layers in Subunit 5d at Site 550. TOC measurements are from shipboard analysis (Cunningham and Waples, this volume). 

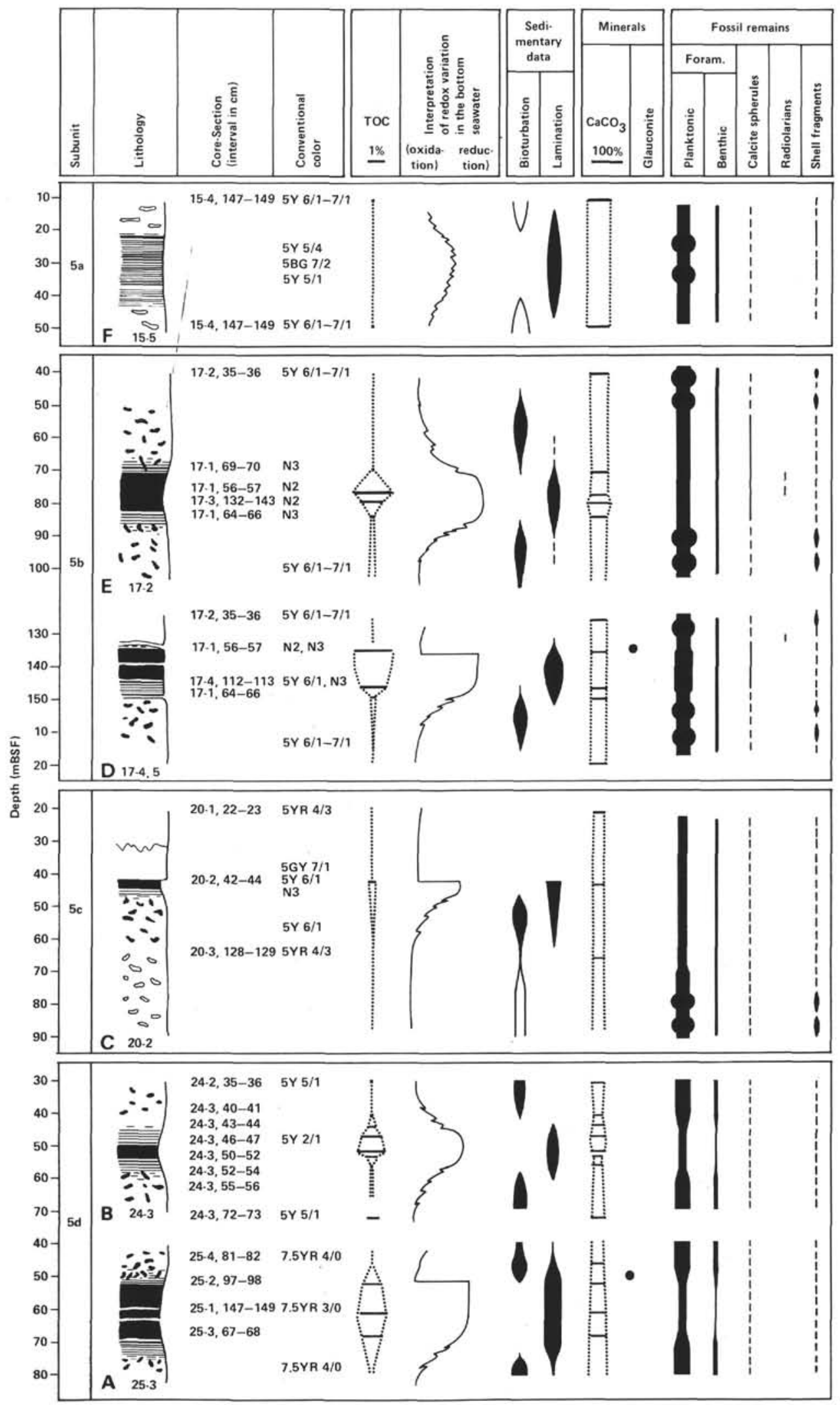

Figure 8. Six basic types of sedimentary cycles (A-F) in the subunits of the upper Albian (Vraconian) to Cenomanian deposits at Site 550. The presence of dark and light-colored burrows is shown by shaded and unshaded symbols, respectively, in the lithology column. $\mathrm{CaCO}_{3}$ and $\mathrm{TOC}$ determinations are from shipboard analysis (Waples and Cunningham, this volume). Glauconite as determined from X-ray diffraction is from G. S. Odin (personal communication, 1982). Calcitic spherules are sparite infills of isolated foraminifer chambers; data are from visual inspection of cores and from thin-section examination. 


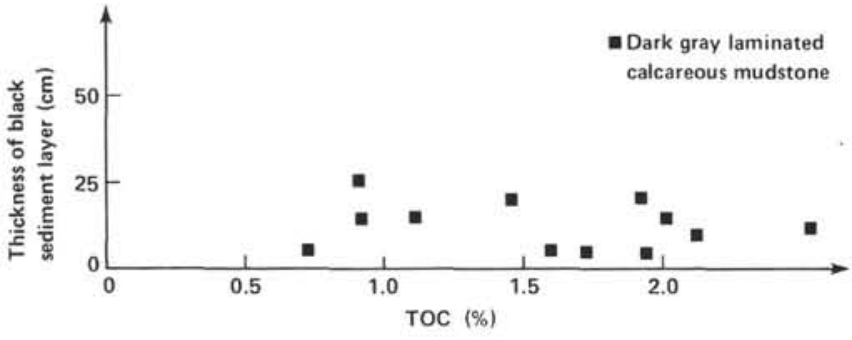

Figure 9. Parallel trends in TOC and $\mathrm{CaCO}_{3}$ contents in a black shale unit (550B-24-3) (from Waples and Cunningham, this volume). The higher carbonate and carbon values in the dark layer could be the result of higher biogenic productivity. A slightly higher influx of terrigenous quartz and clays in the interval low in organic matter could also explain the difference.

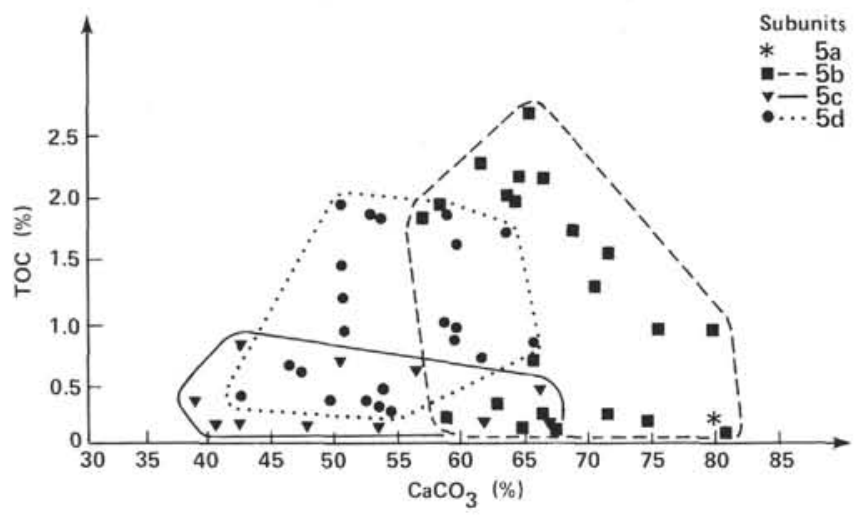

Figure 10. Relationship between TOC and $\mathrm{CaCO}_{3}$ contents of upper Albian (Vraconian) to Cenomanian sediments at Site 550. TOC and $\mathrm{CaCO}_{3}$ determinations are from shipboard analysis (Waples and Cunningham, this volume).

gray, weakly burrowed calcareous mudstone; and (6) light gray, burrowed calcareous mudstone, followed again by (1) light gray, strongly burrowed calcareous mudstone. The replacement of one type of environment by the other was probably progressive.

The other basic sedimentary cycle (Fig. 8A) is asymmetric, but the change from light gray to carbonaceous laminated sediment is also gradational. The carbonaceous laminated part of the cycle, however, is overlain by the light gray part along a sharp surface which is marked by glauconite formed in situ. A typical succession from top to bottom is as follows: (1) light gray, strongly burrowed calcareous mudstone; (2) a thin surface band with in situ glauconite; (3) dark gray, laminated calcareous mudstone; (4) medium gray, weakly burrowed calcareous mudstone; and (5) light gray, burrowed calcareous mudstone, followed again by (1) light gray strongly burrowed calcareous mudstone.

The asymmetry of the cycle and the glauconite formation at the sharp boundary between the two lithologic end members suggests that (1) the confinement of the bottom water occurred progressively in a previously oxygenated environment; (2) sedimentation was interrupted for a period at the end of the time of temporary restriction, allowing the in situ formation of glauconite; and
(3) sedimentation resumed with only residual (i.e., altered) organic matter. The interruption of sedimentation can be related to a renewal of the bottom current pattern, although apparently the currents were temporarily too strong for the deposition of very fine calcareous mud.

Subunit 5c: Alternating Dark Gray, Laminated and Varicolored, Burrowed Calcareous Mudstone

The age of Subunit $5 \mathrm{c}$ is late early to early middle Cenomanian. The thickness is $32.8 \mathrm{~m}$, from $651.5 \mathrm{~m}$ to $618.7 \mathrm{~m}$ BSF (550B-21-5 to 550B-18-2, $20 \mathrm{~cm}$ ). Upper and lower boundaries are transitional.

\section{Lithologic Types}

\section{Varicolored Burrowed Calcareous Mudstone}

The light-colored and organic-carbon-poor mudstone (TOC: $0.1-0.2$ ) differs from the underlying subunit by its reddish to reddish-gray color $(5 \mathrm{YR}, 5 \mathrm{Y})$ and reddish $(10 \mathrm{R})$ or greenish mottling $(5 \mathrm{GY}, 5 \mathrm{G}) . \mathrm{CaCO}_{3}$ contents are 40 to $60 \%$. Pyrite and organic matter were not observed in thin section. Glauconite is rare, and very rare quartz seems to be linked to the presence of agglutinating arenaceous foraminifers. Other textural characteristics and components are similar to those of the light gray mudstone in the underlying subunit.

\section{Dark Gray Laminated Calcareous Mudstone}

This unit is similar to the underlying unit, but it has a more variable $\mathrm{CaCO}_{3}$ content (40-65\%), a lower TOC content $(0.6-0.7 \%)$, and fewer quartz grains.

\section{Mineralogic Components (Fig. 5)}

The dominating clay mineral is smectite $(95 \%$ or higher); there is very little illite. This reduced detrital character of the clay mineral assemblage (in comparison with the underlying subunits) compares well with the trace amounts of quartz detected by bulk-rock X-ray diffraction analysis.

\section{Organic Geochemistry Data (Fig. 5)}

As can be expected from the reddish color of the sediments (implying high oxidation), the maximum TOC is overall lower for the subunit than for the underlying one. Marine organic matter is nearly absent even in the dark facies where organic matter is mainly residual (Waples and Cunningham, this volume).

\section{Cyclic Sedimentation and Proposed Paleoenvironmental Reconstruction}

The basic sedimentary succession $(0.50-1 \mathrm{~m}$ thick) is as follows: (1) reddish (YR), calcareous mudstone with yellowish (5Y or GY) mottling; (2) light gray, bioturbated calcareous mudstone; (3) dark gray, laminated calcareous mudstone; and (4) light gray, bioturbated calcareous mudstone, followed again by (1) reddish, calcareous mudstone with yellowish mottling.

In this case, the lithologic changes are gradational; but in some other occurrences, the light gray mudstone 
is absent at the top of the dark gray layer. In these cases, the typical succession is the following one, from the top to the bottom (Fig. 8C): (1) reddish (YR), calcareous mudstone with yellowish mottling (rapid to sharp contact); (2) dark gray, laminated calcareous mudstone; and (3) light gray, bioturbated mudstone, followed again by (1) reddish, calcareous mudstone with yellowish mottling.

The small maximum grain size in all lithologies implies deposition in a low energy environment. The omission of one member in the cycle can be tentatively explained by nondeposition resulting from temporarily higher energy.

The cyclic character disappears toward the top of the subunit. In comparison with the previously deposited beds, it appears that oxidizing conditions prevailed which allowed the preservation of residual organic carbon only during short periods of time. At the time when deposition of the subunit ended, oxidizing conditions were again dominant.

\section{Subunit 5b: Alternating Light-Colored Burrowed and Dark Gray Laminated Calcareous Mudstone}

This subunit is middle Cenomanian and it is $21.85 \mathrm{~m}$ thick, located 618.7 to $596.8 \mathrm{~m}$ BSF (550-18-2, $20 \mathrm{~cm}$ and $550-15-6,35 \mathrm{~cm})$. The main difference between this and the under- and overlying subunits is the presence of dark gray laminated carbonaceous beds (Figs. 9, 10, and 11).

\section{Lithologic Types}

\section{Light-Colored Burrowed Calcareous Mudstone}

The color is usually gray with various hues of light gray (N6) to yellowish gray (5Y $6 / 1$ to $5 \mathrm{Y} 7 / 1)$ with dark gray mottling (N3 to N5) due to intense bioturbation. Thickness of individual beds is from 0.2 to $1 \mathrm{~m}$. The basal contact is generally sharp but the upper one is gradational.

The $\mathrm{CaCO}_{3}$ contents are higher $(60-80 \%)$ than in Subunit $5 \mathrm{c}$ and the TOC content is again very low (less than $0.25 \%$ ). As observed in thin sections, the microfacies is the same as in Subunit $5 \mathrm{c}$ containing predominantly planktonic foraminifers (hedbergellids, Rotalipora, Schackoi$n a$, and Heterohelix). Rare pyrite is concentrated within the burrows. No glauconite grains were observed, but occasional bands of diffused glauconite were seen. Diagenetic alterations are limited to the transformation of the micritic matrix to microspar around local accumulations of Inoceramus prisms.

\section{Dark Laminated Calcareous Mudstone}

The dark (N2, N3, N4) mudstone occurs in beds of $20 \mathrm{~cm}$ maximum thickness which are very thinly laminated. The TOC content ranges from 0.7 to $2.4 \%$, with maximum values higher than in comparable facies of the lowest Subunit $5 \mathrm{~d} . \mathrm{CaCO}_{3}$ percentages range from 57 to $80 \%$, which is also higher than in lower facies. Under the microscope, the most conspicuous components are tiny flakes of organic matter and small pyrite

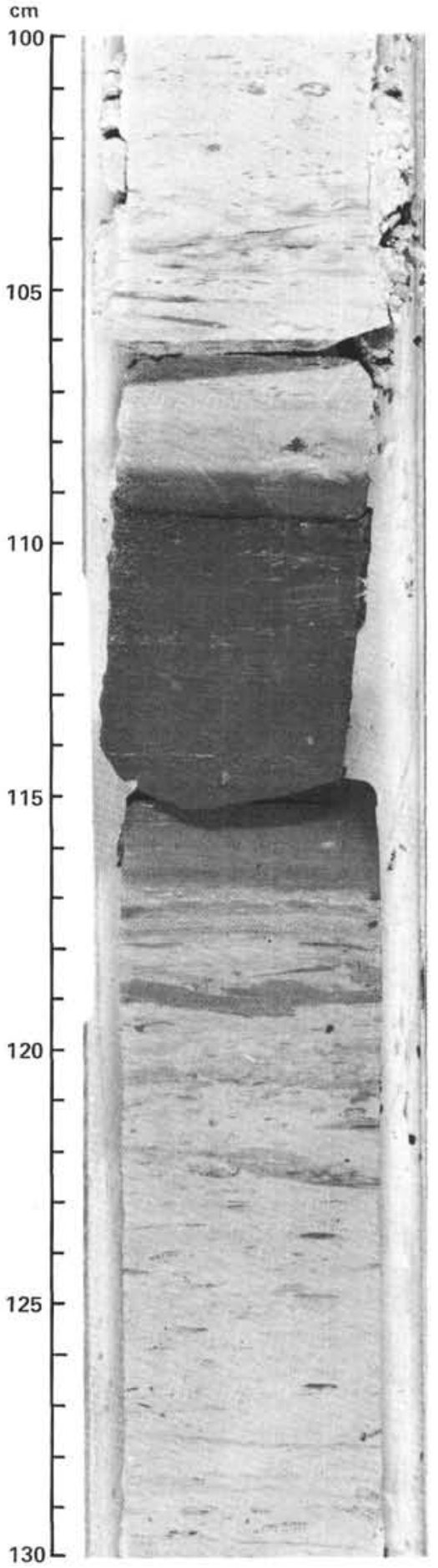

Figure 11. Subunit 5b, 550B-17-2. Photograph of a typical core through a layer of carbonaceous, laminated, calcareous mudstone interbedded with light-colored calcareous mudstone. Note extensive and large-scale bioturbation in the light-colored lithology in contrast to the rare and small burrows that barely affect the lamination in the dark layer. Upper and lower boundaries of the dark layer are gradational, but the transitional interval is much thinner at the upper boundary than at the lower one. The TOC near the top of the dark layer is $1.64 \%$; it is less than $0.1 \%$ in the light-colored mudstone. Glauconite impregnates the burrows at $105-106 \mathrm{~cm}$. In this subunit, $\mathrm{CaCO}_{3}$ contents are between 65 and $70 \%$; they are slightly lower in the dark lithology. 
grains, which produce the typical coloration; planktonic foraminifers and other bioclasts are also observable.

\section{Mineralogic Components (Fig. 5)}

Quartz is just barely detectable by X-ray diffraction methods. The clay minerals represent only 10 to $25 \%$ of the bulk sediment and are composed almost entirely of smectite with some minor illite and mixed-layer clays. This assemblage illustrates a much reduced terrigeneous influx.

\section{Organic Geochemistry Data}

In the dark lithology the TOC reaches its maximum (as high as $2.4 \%$ ) for the whole site. Parallel trends in the TOC and $\mathrm{CaCO}_{3}$ contents can be observed within each depositional cycle (Fig. 9). There is no direct correlation, however, between the TOC content and the thickness of the bed, as seems to be the case in Subunit 5d, nor is there a correlation between $\mathrm{TOC}$ and $\mathrm{CaCO}_{3}$ contents (Fig. 10).

\section{Cyclic Sedimentation and Reconstruction of Paleoenvironment}

As in Subunit 5d, two types of cycles occur in Subunit $5 \mathrm{~b}$ (Figs. 8D, 8E, and 11). The asymmetric (i.e., rhythmic) cycles, in which a short interruption of sedimentation is underlain by a sharp glauconitic surface along the top of the dark facies (Fig. 8D), are less frequent. Unburrowed laminated carbonaceous deposits alternating with strongly burrowed organic-carbon-depleted beds again suggests the alternation of periods of restriction and oxidization in the bottom waters. In spite of the relatively high TOC, however, the importance of organic matter of Type II is lower in the dark facies of Subunit $5 \mathrm{~b}$ than in Subunit $5 \mathrm{~d}$, suggesting a less pronounced restriction (Waples and Cunningham, this volume).

\section{Subunit 5a: Light-Colored and Varicolored Calcareous Mudstone}

This interval is only $2.5 \mathrm{~m}$ thick, represents the end of the middle Cenomanian deposits, and lies between 596.85 and $594.35 \mathrm{~m}$ BSF (550-15-6, $35 \mathrm{~cm}$ to $550-15-4$, $87 \mathrm{~cm}$ ). The upper boundary is a sharp surface with extensive burrowing which underlies lower Senonian argillaceous black shale (Figs. 5 and 6).

The main lithologic types are alternating, yellowish, homogeneous calcareous mudstone and laminated marly chalk with bluish-green to greenish (5BG 7/2, 5Y 6/1) laminations. Burrowing is pervasive. The $\mathrm{CaCO}_{3}$ content is high (maximum of about $80 \%$ ). Quartz is very rare; the clay mineral assemblage is dominated by smectite. The TOC is low $(0.05 \%)$. Fossil components are mainly planktonic foraminifers (hedbergellids, Rotalipo$r a$, and Heterohelix) and scattered tiny shell debris; benthic foraminifers (Ataxophragmiidae) and radiolarians are very uncommon. No glauconite has been observed in thin section. From their lithologic character, it appears that these layers have also been deposited in a consistently low-energy well-oxygenated environment.

\section{Conclusion: Evolution of the Paleoenvironment at Site 550}

The almost 91-m-thick calcareous mudstone layer of Vraconian to middle Cenomanian age at Site 550 shows varying sedimentologic parameters, particularly: (1) a general increase in the $\mathrm{CaCO}_{3}$ content and a decrease in detrital minerals upward; (2) cyclic deposition; and (3) variations in the oxygenation of the bottom waters, possibly related to deep currents.

The increase in the average $\mathrm{CaCO}_{3}$ content up-section is also reflected on the $\gamma$-ray curve (Fig. 5) and appears to be related to an increased abundance of biogenic components (nannofossils and planktonic foraminifers). In contrast, detrital quartz is at a maximum ( $25 \%)$ at the bottom of the sequence, which directly overlies basalt, but it is barely detectable by X-ray diffraction at the top of the section. A similar evolution is exhibited by the clay minerals. An association of smectite, illite, chlorite, and mixed-layer clays at the bottom changes upward to nearly pure smectite. Thin-section examination shows the decrease of plant fragments from the bottom to the top.

The mode of deposition was mainly cyclic, which was on two orders of scale. On the scale of several meters, fluctuations in the TOC maxima and in the dominant colors have allowed the distinction of four subunits (Table 1). At the scale of 10 to $100 \mathrm{~cm}$, two kinds of alternating lithologies can be clearly distinguished on the basis of color and organic-carbon content. The facies suggest fluctuations in oxygen content in the bottom waters. Laminated carbonaceous mudstone beds are often separated from overlying light-colored burrowed mudstone beds by surfaces or thin intervals encrusted with diffuse glauconite, the presence of which suggests a temporary interruption of sedimentation by bottom currents (Odin and Stephan, 1981). This glauconite is different from well-defined, rounded grains of glauconite which were probably reworked from shallower depths. The lower contacts of the laminated mudstone beds, however, are always transitional. All this suggests that there was a gradual evolution from oxygenated to restricted conditions superimposed on a shorter term periodic renewal of the oxygen content by bottom currents. In the absence of currents the environment would certainly have remained restricted for a longer time during the Cenomanian.

Table 1. Characteristics of mudstones within the four subunits in the Vraconian to Cenomanian sequence at Site 550.

\begin{tabular}{|c|c|c|c|c|}
\hline Subunit & $\begin{array}{l}\text { Thickness } \\
\text { (m) }\end{array}$ & $\begin{array}{l}\text { Mudstone } \\
\text { lithology }\end{array}$ & Color & $\begin{array}{c}\text { Maximum } \\
\text { TOC } \\
(\%)\end{array}$ \\
\hline \multirow[t]{2}{*}{$5 \mathrm{a}$} & \multirow[t]{2}{*}{2.5} & Laminated burrowed & Varicolored & $<0.1$ \\
\hline & & Laminated carbonaceous & Dark gray & 2.4 \\
\hline \multirow[t]{2}{*}{$5 b$} & \multirow[t]{2}{*}{21.85} & Burrowed & Light gray & 0.25 \\
\hline & & Laminated & Dark gray & 0.7 \\
\hline \multirow[t]{2}{*}{$5 \mathrm{c}$} & \multirow[t]{2}{*}{32.8} & Burrowed & Pinkish & $<0.1$ \\
\hline & & Laminated carbonaceous & Dark gray & 1.85 \\
\hline $5 d$ & 33.7 & Burrowed & Light gray & 0.5 \\
\hline
\end{tabular}


The average duration of one cycle involving one couplet of dark/light layers has been estimated at 45,000 years for Subunit $5 \mathrm{~d}$ and at 32,000 years for Subunit $5 \mathrm{~b}$. The value of 45,000 years compares particularly well with the 43,000-year cycle of orbital obliquity (Schwarzacher and Fischer, 1982). This means that the observed sedimentary alteration could have been climatically induced.

\section{SUMMARY}

At Sites 549 and 550, alternating dark and light-colored calcareous mudstones and siltstones of mid-cretaceous age were recovered. In spite of their different ages (Albian at Site 549 and Cenomanian at Site 550), each section shows alternating burrowed, organic-carbon-depleted sediments and nonburrowed, laminated carbonaceous sediments, often with gradational contacts between them. In other cases, sharp contacts encrusted with diffuse glauconite separate the dark sediments below from the light-colored sediments above. This suggests a temporary interruption of sedimentation, perhaps under the influence of weak bottom currents (Odin and Stephan, 1982). These observations lead to the model of an oxygen-depleted environment (as is indicated by preserved organic matter) with periodic renewal and reoxygenation of bottom waters by currents. This view is probably valid for the Cenomanian sequence at Site 550 where the dark lithology contains marine organic matter (Type II on the Van Krevelen diagram) (Waples and Cunningham, this volume) which is particularly susceptible to oxidation. This interpretation is supported by the absence of burrowing in the laminated organic-carbon-rich sediments because burrowing animals do not prosper in oxygen-depleted waters. Varying proportions of other components, such as quartz, calcite, clay minerals, and planktonic biota in both the dark and light-colored sediments also suggest that oxygen content in the bottom waters was the most influential variable.

In other circumstances in which high and low TOC contents are associated with different lithologies, such oscillations in the dissolved oxygen content become more questionable. Such was the case for the Albian sediments of DSDP Site 400 (north Biscay Bay transect, Leg 48 ) in which carbonaceous noncalcareous beds alternate with noncarbonaceous calcareous beds. Two models have been proposed to explain this type of alternating sequence. One model suggests variations in the oxygen content of the bottom waters (Mélières, 1979); the other model postulates the redeposition of calcareous mudstone within a restricted environment located below the carbon compensation depth (Graciansky and Chenet, 1979). But there is no sedimentologic evidence to support the idea of redeposition at Sites 549 and 550.

The environment reconstructed for the Albian at Site 549 is somewhat different from the interpreted paleoenvironment at Site 550 because the dark lithology has a relatively low TOC content $(<1 \%)$ derived from terrestrial or residual organic matter. Because this type of organic matter is not very susceptible to oxidation, oxygen depletion is not required for its preservation.

During Albian time, water depths at Site 549 on the top of the Pendragon Escarpment was probably less than
$500 \mathrm{~m}$ (Masson et al., this volume). A relatively high terrigenous influx is documented by a large amount of quartz (maximum $25 \%$ ) and a variable clay mineral assemblage, particularly in the dark facies. In contrast at Site 550 the reconstructed water depth for Cenomanian time was probably greater than $2000 \mathrm{~m}$ (Masson et al., this volume). The terrigenous influx at Site 550 was apparently much smaller because quartz occurs only in traces, and the clays are dominated by smectite.

At Site 549 abundant radiolarians are the main planktonic fossil, and they occur along with terrestrial organic matter. This contrasts to Site 550, which is characterized by an abundance of planktonic foraminifers (and a scarcity of radiolarians), along with marine organic matter. This contradicts the general assumption of a positive correlation among high productivity, abundant radiolarians, and a high content of marine organic matter.

The average duration of one cycle involving one couplet of dark/light layers has been estimated as 20,000 years at Site 549 and as 45,000 years and 32,000 years for Subunit $5 \mathrm{~b}$ at Site 550 . The duration of 20,000 years correlates with the Earth's 19,000-23,000-year orbital precession. The duration of 45,000 years compares well with the 43,000-year cycle of obliquity (Schwarzacher and Fischer, 1982). (The cycle of 32,000 years is uncertain due to the poor recovery of the corresponding cores at Site 550, Subunit 5b.) These correlations suggest that the observed cycles may be climatically induced through variations in oceanic turnover and oxygenation of bottom waters. But the difference in the average duration of one individual cycle between the Albian at Site 549 and the Cenomanian at Site 550 shows that initial causes may have been different.

Of particular interest is the episodic presence of sediments indicative of oxygen-depleted environments at Site 550 at a depth of approximately $2000 \mathrm{~m}$ (Masson et al., this volume) of early to middle Cenomanian age deposited contemporaneously with sediments suggesting wellaerated environments at a shallower depth of 1000 to $1200 \mathrm{~m}$ at Site 549 where white chalks were deposited (Graciansky and Bourbon, this volume). This apparently demonstrates the occasional existence of trapped waters during the first stages of the opening of the Mid-Atlantic rift.

The variegated reddish deposits near the boundary of the lower/middle Cenomanian at Site 550 can be correlated with a highly condensed sequence of Cenomanian variegated clays at Site 398 located on the Iberian margin. A recent stratigraphic study (Sigal, in Graciansky et al., 1982) has demonstrated the scarcity of sites in the open deep Atlantic Ocean with preserved sediments of late early and middle Cenomanian age resulting from nondeposition or erosion during the Cenozoic. Middle Cenomanian sediments have been preserved in peculiar structural conditions at Sites 137 (Hayes, Pimm, et al., 1972), Sites 386 and 387 (Tucholke, Vogt, et al., 1979), and Site 398 on the Iberian margin where the sedimentation rate was particularly high (Sibuet, Ryan, et al., 1979). The presence of similar Cenomanian deposits at Site 550 may be a result of ponding and protection from subsequent erosion in a narrow depression. 


\section{ACKNOWLEDGMENTS}

The authors are indebted to $\mathrm{M}$. Thiry who carried out the X-ray determinations in the Laboratory of Mineralogy at École des Mines. They are also grateful to G. S. Odin for having carefully examined and determined some selected glauconites and to Mrs. F. Magniez who determined the main foraminifer assemblages. Fruitful discussions were held with R. Cunningham, G. Deroo, J. P. Herbin, C. Müller, J. Sigal, and D. Waples. This work was undertaken with the help of the Centre National de la Recherche Scientifique (Action no. 955066). Special thanks are due to D. Bernoulli, M. Hart, D. Masson, and D. Waples who agreed to review the first version of this text. Many fruitful suggestions have been brought by D. Bernoulli and C. W. Poag for the final form of this paper.

\section{REFERENCES}

Graciansky, P. C. de, Auffret, G. A., Dupeuble, P., Montadert, L., and Müller, C., 1979. Interpretation of depositional environments of the Aptian-Albian Black Shales on the north margin of the Bay of Biscay (DSDP Sites 400 and 402). In Montadert, L., Roberts, D. G., et al., Init. Repts. DSDP, 48: Washington (U.S. Govt. Printing Office), 877-908.

Graciansky, P. C. de, Brosse, E., Deroo, G., Herbin, J.-P., Montadert, L., Müller, C., Sigal, J., and Schaaf, A., 1982. Les formations d'âge Crétacé de l'Atlantique Nord et leur matière organique. Rev. Inst. Fr. Pet., 37:275-337.

Graciansky, P. C. de, and Chenet, P. Y., 1979. Sedimentological study of Cores 138 to 56 (upper Hauterivian to middle Cenomanian): An attempt at reconstruction of paleoenvironments. In Sibuet, J. C., Ryan, W. B. F., et al., Init. Repts. DSDP, 47, Pt. 2: Washington (U.S. Govt. Printing Office), 403-418.
Hayes, D. E., Pimm, A. C., et al., 1972. Init. Repts. DSDP, 14: Washington (U.S. Govt. Printing Office).

Karpoff, A.-M., Hoffert, M., and Clauer, N., 1981. Sedimentary sequences at Deep Sea Drilling Project Site 464: Silicification processes and transition between siliceous biogenic oozes and brown clays. In Thiede, J., Vallier, T. L., et al., Init. Repts. DSDP, 62: Washington (U.S. Govt. Printing Office), 759-772.

Kastner, M., Keene, J. B., and Gieskes, J. M., 1977. Diagenesis of siliceous oozes. I. Chemical controls on the rates of Opal-A to OpalCT transformation, an experimental study. Geochim. Cosmochim. Acta, 41:1041-1059.

Mélières, F., 1979. Mineralogy and geochemistry of selected Albian sediments from the Bay of Biscay, Deep Sea Drilling Project, Leg 48. In Montadert, L., Roberts, D. G., et al., Init. Repts. DSDP, 48: Washington (U.S. Govt. Printing Office), 855-876.

Odin, G. S., and Stephan, J. F., 1982. The occurrence of deep water glaucony from the eastern Pacific: the result of in situ genesis or subsidence. In Watkins, J.-S., Moore, J. C., et al., Init. Repts. $D S D P, 66$ : Washington (U.S. Govt. Printing Office), 419-428.

Schwarzacher, W., and Fischer, A. G., 1982. Limestone-shale bedding and perturbation of the earth's orbit. In Einsele, G., and Seilacher, A. (Eds.), Cyclic and Event Stratification: New York (SpringerVerlag), pp. 72-95.

Sibuet, J. C., Ryan, W. B. F., et al., 1979. Init. Repts. DSDP, 47, Pt. 2: Washington (U.S. Govt. Printing Office),

Tucholke, B. E., Vogt, P. R., et al., 1979. Init. Repts. DSDP, 43: Washington (U.S. Govt. Printing Office).

Date of Initial Receipt: December 14, 1982

Date of Acceptance: August 15, 1983 